A history of

humanitarianism,

1755-1989

In the name of others

$\frac{1}{2+3}$

1.

Silvia Salvatici 


\section{A history of humanitarianism, 1755-1989}

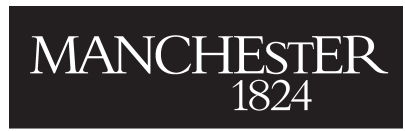

Manchester University Press 


\section{HUMANITARIANISM}

\section{SERIES EDITOR: BERTRAND TAITHE}

This series offers a new interdisciplinary reflection on one of the most important and yet understudied areas in history, politics and cultural practices: humanitarian aid and its responses to crises and conflicts. The series seeks to define afresh the boundaries and methodologies applied to the study of humanitarian relief and so-called 'humanitarian events'. The series includes monographs and carefully selected thematic edited collections which cross disciplinary boundaries and bring fresh perspectives to the historical, political and cultural understanding of the rationale and impact of humanitarian relief work.

\section{Islamic charities and Islamic humanism in troubled times} Jonathan Benthall

Humanitarian aid, genocide and mass killings: Médecins Sans Frontières, the Rwandan experience, 1982-97 Jean-Hervé Bradol and Marc Le Pape

Calculating compassion: Humanity and relief in war, Britain 1870-1914 Rebecca Gill

Humanitarian intervention in the long nineteenth century Alexis Heraclides and Ada Dialla

The military-humanitarian complex in Afghanistan Eric James and Tim Jacoby

Global humanitarianism and media culture Michael Lawrence and Rachel Tavernor (eds)

Donors, technical assistance and public administration in Kosovo Mary Venner

The NGO CARE and food aid from America 1945-80: 'Showered with kindness'? Heike Wieters 


\section{A history of humanitarianism, 1755-1989}

In the name of others

Silvia Salvatici

Translated by Philip Sanders

Manchester University Press 


\section{Copyright (C) Silvia Salvatici 2019}

The right of Silvia Salvatici to be identified as the author of this work has been asserted by her in accordance with the Copyright, Designs and Patents Act 1988.

First published as Nel nome degli altri. Storia dell'umanitarismo internazionale in 2015, by Società editrice il Mulino

First English-language edition published in 2019 by Manchester University Press Altrincham Street, Manchester M1 7 JA

www.manchesteruniversitypress.co.uk

ISBN 9781526120144 hardback

ISBN 9781526120168 paperback

The publisher has no responsibility for the persistence or accuracy of URLs for any external or third-party internet websites referred to in this book, and does not guarantee that any content on such websites is, or will remain, accurate or appropriate.

Typeset in Arno and Univers by R. J. Footring Ltd, Derby 
A history of humanitarianism, 1755-1989: In the name of others is an extended and updated edition of Nel nome degli altri. Storia dell'umanitarismo internazionale, published in 2015 by Società editrice il Mulino and translated into English by Philip Sanders. 
Silvia Salvatici - 9781526120151 Downloaded from manchesterhive.com at 04/26/2023 05:45: 03 AM via free access 